\title{
Kepastian Hukum Pendaftaran Persekutuan Komanditer Pada Sistem Administrasi Badan Usaha
}

\author{
Dentria Cahya Sudarsaㅁ, I Wayan Parsa ${ }^{2}$
}

\author{
${ }^{1}$ Program Studi Magister (S2) Kenotariatan, Fakultas Hukum Universitas Udayana, \\ E-mail: dentriasudarsa@gmail.com \\ 2Fakultas Hukum Universitas Udayana, Email :wayan_parsa@unud.ac.id
}

\begin{abstract}
Info Artikel
Masuk: 26 November 2020

Diterima:28 November 2020

Terbit : 15 Desember 2020

Keywords:

Limited Partnership; Legal

Certainty, Business

Administration System.
\end{abstract}

Kata kunci:

Persekutuan Komanditer; Kepastian Hukum, Sistem Administrasi Badan Usaha.

Corresponding Author: Dentria Cahya Sudarsa, I Wayan Parsa

Email: dentriasudarsa@rocketmail.com. Wayan_parsa@unud.ac.id DOI:

10.24843/AC.2020.v05.i03.p09

\begin{abstract}
The writing of this article is based on the issuance of new regulations regarding the establishment and registration of limited partnership /CV in the business administration system $(S A B U)$ in accordance with the provisions of Article 5 paragraph (1) Regulation of the Minister of Law and Human Rights Number 17 of 2018 concerning Registration of Limited Partnerships, Firms, and the Civil Union which previously was only regulated in the Trade Law Book. Type of research used in this article is normative legal research. The purpose of this article is to determine the mechanism and legal certainty in the registration of the Limited Partnership after the enactment of business administration system. The results of the research and writing of this article are that there is an overlap in the registration mechanism for the Limited Partnership based on these two rules, it can be concluded that due to the provisions in KUHD and Minister Regulation No. 17 of 2018 both are still valid, the principle of legal preference can be used, namely lex special is derogat legi lex generalis, means that a more specificlaw can override a more general law. The advice that can be given is to conduct a study of the enactment of the Minister Regulation whether to follow or not the provisions in the Trade Law Books due to avoid conflicting norms in the registration of a limited partnership.
\end{abstract}

\begin{tabular}{l} 
Abstrak \\
\hline Penulisan artikel ini dilatarbelakangi oleh terbitnya peraturan
\end{tabular}
baru tentang pendirian dan pendaftaran Persekutuan Komanditer/CV pada sistemadministrasi badan usaha (SABU) sesuai ketentuan Pasal 5 ayat (1) Peraturan Menteri Hukum dan Hak Asasi Manusia Nomor 17 Tahun 2018 tentang Pendaftaran Persekutuan Komanditer, Persekutuan Firma, dan Persekutuan Perdata yang mana sebelumnya hanya diatur dalam KUHD saja. Jenis penelitian yang digunakan dalam penulisan artikel ini adalah penelitian hukumnormatif. Tujuan dibuatnya artikel ini adalah untuk mengetahui kepastian hukummengenai mekanisme dalam pendaftaran Persekutuan Komanditer setelah berlakunya $S A B U$. Hasil penelitian dan penulisan artikel ini adalah adanya tumpang tindih dalam mekanisme pendaftaran Persekutuan Komanditer berdasarkan kedua aturan tersebut maka dapat diambil kesimpulan bahwa dikarenakan ketentuan dalam KUHD dan Permenkumham No. 17 Tahun 2018 masih berlaku, dapat digunakan asas preferensi hukum yaitu lex specialis derogat legi 
lex generalis yaitu hukum yang lebih khusus dapat mengesampingkan hukumyang lebih umum. Saran yang dapat diberikan adalah dengan melakukan kajian terhadap berlakunya Permenkumham tersebut apakah tetap mengikuti ketentuan dalam KUHD atau tidak untuk menghindari pertentangan norma dalam pedaftaran Persekutuan Komanditer.

\section{Pendahuluan}

Kompleksnya aktivitas dan bidang usaha yang didirikan di Indonesia menandai bahwa minat mendirikan usaha serta perkembangan dalam berusaha terus mengalami peningkatan. Di Indonesia terdapat beberapa macam bentuk badan usaha yang telah diketahui dan didirikan bahkan sejak zaman Pemerintahan Hindia-Belanda, seperti Persekutuan Firma, Commanditaire Vennootschap atau yang kerap disingkat dengan CV, dan perseroan, dimana dalam kegiatan bisnis saat ini seringkali digunakan kata perusahaan. ${ }^{1}$ Istilah usaha, dan perusahaan, tidak terlepas kaitannya dengan sejarah dan perkembangan hukum dagang di Indonesia. Perikatan-perikatan mana yang timbul khususnya dalam lapangan hukum perusahaan disebut sebagai hukum dagang. ${ }^{2}$ Menurut sumber hukumnya terdapat dua pengaturan yang mendasari pengaturan hukum perusahaan di Indonesia yaitu, Kitab Undang-Undang Hukum Dagang (selanjutnya di sebut KUHD) dan Kitab Undang-Undang Hukum Perdata (yang selanjunya disebut KUHPerdata) selain diatur pula dalam peraturan perundang-undangan yang lebih khusus. Ditinjau dari sistem kedudukan peraturan perundang-undangan di Indonesia KUHPerdata merupakan undang-undang yang mengatur hukum keperdataan secara umum, sedangkan KUHD merupakan hukum Perdata Khusus. 3

Salah satu bentuk usaha yang sangat populer yang banyak didirikan di Indonesia adalah Perseroan Terbatas (selanjutnya disebut PT) dan Commanditaire Vennotsschaap atau Persekutuan Komanditer (selanjutnya di sebut CV). Apabila dilihat dari bentuk badan usaha terdapat perbedaan antara PT dan CV, dimana PT merupakan badan usaha yang berbadan hukum sedangkan $\mathrm{CV}$ merupakan badan usaha yang belum berbadan hukum. Hal ini menyebabkan PT banyak digunakan oleh para pengusaha sebagai legalitas dalam menjalankan kegiatan usaha. Namun demikian, tidak sedikit pengusaha yang memilih CV sebagai bentuk badan usahannya sebab dalam proses pendirian $\mathrm{CV}$ dinilai cukup mudah dan murah jika dibandingkan dengan mendirikan sebuah PT.

Dasar hukum pendirian CV sebelum tahun 2018 adalah berdasarkan ketentuan Pasal 23 KUHD yaitu dengan kewajiban untuk mendaftarkan akta pendiriannya di

\footnotetext{
${ }^{1}$ Abdul Rasyid Saliman, 2011, Hukum Bisnis Untuk Perusahaan: Teori Dan Contoh Kasus, Kencana, Jakarta, h. 91-92

2 H.M.N Purwosutjipto, 1995, Pengertian Pokok Hukum Dagang Indonesia: Pengetahuan Dasar Hukum Dagang, Djambatan, Jakarta, h. 11.

${ }^{3}$ Titik Triwulan Tutik, 2008, Hukum Perdata dalam Sistem Hukum Nasional, Kencana, h. 28
} 
Kepaniteraan Pengadilan Negeri di tempat CV tersebut berkedudukan. ${ }^{4}$ Berkembangnya teknologi juga mempengaruhi perkembangan regulasi dan tata cara pendirian dan pendaftaran badan usaha khususnya CV. Namun, ketentuan dalam KUHD dirasa kurang menyesuaikan dengan percepatan dunia usaha sehingga tidak dapat memfasilitasi kebutuhan dan menuntut proses dalam kegiatan berusaha secara cepat mudah dan efisien. Bertolak dengan keadaan tersebut menyebabkan pemerintah Indonesia akhirnya merancang, merumuskan dan menerbitkan regulasi baru yaitu, mengenai Pelayanan Perizinan Berusaha Terintegrasi secara Elektronik, yaitu Peraturan Pemerintah No 24 Tahun 2018 yang mana di dalamnya diatur pula Online Single Submission. Melalui aturan tersebut, kemudian ditindak lanjuti oleh Kementerian Hukum dan Hak Asasi Manusia dengan menerbitkan Peraturan Menteri No. 17 Tahun 2018 tentang Pendaftaran Persekutuan Komanditer, Persekutuan Firma dan Persekutuan Perdata (Selanjutnya disebut Permenkumham No. 17/2018). Berlakunya regulasi Permenkumham No. 17/2018 memberlakukan ketentuan baru bagi pendirian dan pendaftaran $\mathrm{CV}$ yaitu dalam ketentuan Pasal 3 mewajibkan pemohon CV melakukan pendaftaran dan pendirian CV kepada Menteri Hukum dan Hak Asasi Manusia melalui Sistem Administrasi Badan Usaha (SABU) pada Direktorat Administrasi Hukum Umum (AHU) secara elektronik. Dalam pendaftaran CV baik saat berlakunya KUHD maupun setelah diterbitkannya peraturan menteri, memerlukan peranan Notaris sebagai pejabat yang berwenang membuat akta otentik. Perubahan mekanisme pendaftaran $\mathrm{CV}$ sesuai Permenkumhan menimbulkan ketidakpastian hukum dalam pendaftaran CV di Indonesia, dimana terdapat pertentangan norma pendaftaran dan pendirian CV berdasarkan ketentuan KUHD dengan pendaftaran dan pendirian CV sesuai ketentuan Permenkumham No. 17/2018 yang didalamnya tidak menjelaskan apakah ketentuan dalam KUHD telah dicabut ataukah harus tetap dilaksanakan sebagai perintah Undang-Undang. Berdasarkan uraian diatas rumusan permasalahan yang dikaji dalam artikel ini adalah bagaimana kepastian Hukum dalam Pendaftaran CV melalui Sistem Administrasi Badan Usaha serta bagaimana peran Notaris dalam pendaftaran $\mathrm{CV}$ setelah terbitnya Permenkumham No. 17/2018? Penulisan artikel ini bertujuan untuk menganalisa dan mengkaji peran Notaris serta kepastian hukum pendaftaran CV setelah berlakunya Permenkumham No.17 Tahun/2018 dalam sistem administrasi badan usaha.

Berdasarkan artikel yang ditulis oleh Ayu Ratnawati yang dimuat dalam Jurnal Repertorium mengenai peranan Notaris untuk pembuatan Akta pendirian CV dalam Mewujudkan Kepastian Hukum5, yang mana penelitian tersebut menitikberatkan pada peranan Notaris dalam membuat akta pendirian CV sesuai ketentuan KUHD. Sedangkan dalam artikel ini juga berfokus pada peran Notaris dalam Peraturan Menteri yaitu Permenkumham 17 Tahun 2018 yang tidak terbatas hanya pada pembuatan akta pendiriannya saja, namun juga berperan dalam proses pendaftarannya pada Sistem Administrasi Badan Usaha. Selain itu terdapat pula penelitian yang ditulis oleh I Made Hengki Permadi dalam jurnal Acta Comitas,

\footnotetext{
${ }^{4}$ Utami, P. D. Y.(2020). PENGATURAN PENDAFTARAN BADAN USAHA BUKAN BADAN HUKUM MELALUI SISTEM ADMINISTRASI BADAN USAHA. Jurnal Komunikasi Hukum (JKH), 6(1), 1-19, h. 4.

5 Ratnawati, A. (2015). Peranan Notaris Untuk Pembuatan Akta Pendirian (CV) dalam Mewujudkan Kepastian Hukum. Jurnal Repertorium. 2(2)
} 
dimana dalam penulisan tersebut lebih berfokus pada pendaftaran Firma, sedangkan fokus penulisan artikel ini ada pada pendaftaran Persekutuan Komanditer/CV. ${ }^{6}$

\section{Metode Penelitian}

Penulisan artikel ini menggunakan jenis penelitian hukum normatif dengan mengkaji suatu peristiwa hukum atau fakta-fakta hukum berdasarkan norma-norma hukum yang $\mathrm{ada}^{7}$, dalam hal ini terdapat pertentangan norma dalam pendaftaran persekutuan komanditer sebelum dan sesudah berlakunya Permenkumham 17/2018 melalui sistem admisitrasi badan usaha. Pendekatan yang digunakan di dalam penulisan artikel ini ialah (1) pendekatan analisis konsep hukum (analytical and conceptual approach) yang dilakukan dengan menelaah segala permasalahan menurut asas-asas, teori, konsep dan norma hukum atau peraturan-peraturan hukum yang berlaku di Indonesia, (2) pendekatan perundangan-undangan (the statue approach) yaitu dengan mengkaji, dan menganalisis asas, norma, konsep, serta prinisp yang termuat di dalam peraturan-peraturan hukum yang mengatur mengenai permasalahan yang akan dibahas. Penulisan artikel ini diterapkan dengan menelaah sumber bahan hukum primer, sekunder, dan tersier, bahan hukum yang disebutkan itu ialah berupa peraturan perundang-undangan, literature atau buku-buku, dan kamus-kamus, serta sumber-sumber internet. ${ }^{8}$

Teknik studi dokemen/kepustakaan digunakan dengan cara, pengumpulan bahan hukum selanjutnya dilakukan penyusunan secara sistematis sesuai dengan urutan persoalan hukum yang akan dianalisis di dalam penulisan penelitian maka selanjutnya dilakukan analisis dan kajian mengenai bahan-bahan yang didapatkan yang memiliki keterkaitan mengenai inti persoalan yang akan dibahas dan dilakukan evaluasi, serta diberikan argumentasi, di analisis dan dikaji untuk diterapkan sebagai dasar mengambil kesimpulan mengenai permasalahan yang di bahas di dalam penelitian.

\section{Hasil dan Pembahasan}

\subsection{Peranan Notaris dalam Pendaftaran dan Pendirian Persekutuan Komanditer Setelah Berlakunya Sistem Administrasi Badan Usaha}

Maatschap atau vennootschap dalam Bahasa Belanda, di Indonesia dikenal sebagai Persekutuan yang merupakan perjanjian yang dilakukan oleh dua orang atau lebih dengan cara memasukkan sejumlah kekayaannya dan dijadikan sebagai modal dasar dengan tujuan untuk melakukan usaha secara bersama-sama demi mencapai dan meraih keuntungan dari usaha tersebut. ${ }^{9}$ Berdasarkan pendapat para ahli, dapat disimpulkan bahwa $\mathrm{CV}$ adalah suatu bentuk usaha dimana satu orang atau lebih

\footnotetext{
${ }^{6}$ Permadi, I. M. H. (2019). Pengaturan Mengenai Pendaftaran Pendirian Firma Pada Sistem Administrasi Badan Usaha. Acta Comitas: Jurnal Hukum Kenotariatan, 4(3).

'Barus, Z. (2013). Analisis Filosofis Tentang Peta Konseptual Penelitian Hukum Normatif Dan Penelitian Hukum Sosiologis. Jurnal Dinamika Hukum, 13(2), 307-318.

8Permana, I. G. A. (2019). Penggunaan Upaya Hukum Novasi Dalam Penyelesaian Permasalahan Hukum Perusahaan Yang Mengalami Kerugian. Acta Comitas: Jurnal Hukum Kenotariatan, 4(2).

${ }^{9}$ Subekti, 1995, Aneka Perjanjian, PT. Citra Aditya Bakti, Bandung, hal. 75-76.
} 
mempercayakan dengan menyetorkan sejumlah uangnya kepada satu orang datu lebih yang bertanggung jawab secara keseluruhan untuk mengurus menjalankan kegiatan usahanya dalam persero tersebut. ${ }^{10}$

Pengaturan mengenai Perseroan Komanditer diatur dalam ketentuan Pasal 19 sampai dengan Pasal 35 KUHD namun KUHD tidak secara spesifik mengatur mengenai CV saja melainkan menyangkut juga mengenai Persekutuan Firma. Perbedaan yang terdapat dalam CV maupun Perseroan Komanditer juga diatur dalam Pasal 19-21 KUHD yaitu dikenalnya sekutu pelepas uang atau sekutu komanter yang merupakan sekutu pasif atau sekutu diam yang hanya bertindak dan mempercayakan sejumlah modal yang disetorkan ke dalam $\mathrm{CV}$ dan tidak turut serta dalam pengurusan $\mathrm{CV}$. Dengan kata lain, CV merupakan badan usaha yang selain terdiri dari beberapa sekutu yaitu Sekutu Komplementer dan Sekutu Komanditer, sedangkan dalam Persekutuan Firma hanyalah dikenal sekutu kerja atau firmant. ${ }^{11}$ Yang dimaksud dengan sekutu komanditer dalam hal ini adalah sekutu penyerta modal yang tanggung jawabnya hanya terbatas pada modal yang disetorkan ke dalam perseroan begitu pula keuntungan yang diperoleh hanya terbatas pada modal yang diberikan oleh sekutu komanditer tersebut hal ini juga menyebabkan sekutu komanditer tidak memiliki kewenangan untuk turut campur dalam pengurusan persekutuan dan juga tidak diberikan kewenangan untuk melakukan segala perbuatan hukum yang melibatkan pihak ketiga yang mengatas namakan CV tersebut. Berlainan dengan sekutu komplementer yang juga disebut sebagai sekutu aktif merupakan sekutu yang melakukan segala pengurusan dan melakukan segala perbuatan hukum yang melibatkan pihak ketiga. Sekutu aktif bertanggung jawab sepenuhnya sampai dengan harta kekayaanya baik dalam hal mendapatkan keuntungan maupun kerugian berdasarkan ketentuan Pasal 18 KUHD jo. Pasal 1131, 1132 KUHPerdata. ${ }^{12}$ Sekutu pasif atau istilah lainnya sekutu komanditer hanya berfungsi sebagai pelepas uang, yaitu orang yang mempercayakan uangnya dan yang memiliki tanggung jawab dalam menjalankan perusahaan tersebut merupakan komplementaris atau sekutu pengurus. Sekutu komanditer tidak diberi kewenangan untuk turut campur dalam tugas sekutu komplementer atau sekutu pengurus. Sekutu komplementer adalah sekutu pengurus atau sekutu kerja dan sekutu komanditer sebagai sleeping partners atau sekutu diam.

Dalam hal pendaftaran dan pendiriannya, terdapat dua sumber hukum dalam pengaturan CV yaitu berdasarkan Pasal 23 KUHD dan yang berdasarkan Permenkumham No. 17 Tahun 2018 Tentang Pendaftaran Persekutuan Komanditer, Persekutuan Komanditer, Persekutuan Firma dan Persekutuan Perdata. Dalam kedua aturan tersebut terdapat persamaan yaitu memerlukan adanya akta pendirian yang wajib dibuat di hapadan Notaris.

Pasal 15 ayat (1) Undang- Undang Nomor 2 Tahun 2014 tentang perubahan atas Undang-undang Nomor 30 Tahun 2004 tentang Jabatan Notaris (Selanjunya disebut UUJN-P) menyatakan bahwa kewenangan Notaris sebagai pejabat yang berwenang

10 Partyani, K. C. M. (2019). PERTENTANGAN NORMA DALAM PENGATURAN PENDAFTARAN DAN PENDIRIANCOMMANDITAIRE VENNOOTSCHAP (CV). Vyavahara Duta, 14(1), 68-77.

11 I.G.Rai Widjaya, 2007, Hukum Perusahaan, Kesaint Blanc, Bekasi,hal. 51

${ }^{12}$ I.G.N Rai Widjaya, ibid, hal.52. 
untuk membuat akta otentik mengenai semua perbuatan dan perjanjian yang diwajibkan oleh suatu peraturan perundang-undangan dan oleh orang yang berkepentingan untuk dinyatakan dalam suatu akta otentik. ${ }^{13}$ Pasal 22 KUHD menyatakan bahwa tiap perseroan wajib dibuat dengan akta otentik. Dengan adanya ketentuan tersebut diatas, telah dengan tegas ditentukan mengenai ketentuan pendirian $\mathrm{CV}$ dengan membuat akta otentik merupakan kewenangan yang dimiliki oleh seorang Notaris. Tata cara pendaftaran CV dalam KUHD diatur dalam Pasal 23 adalah dengan cara mendaftarkan akta pendirian kepada Panitera Pengadilan yang berwenang yaitu dimana persekutuan komanditer tersebut berkedudukan, dan kemudian terdapat kewajiban mengumumkan pendaftaran CV tersebut ke dalam ihtisar resmi dan memuatnya dalam Tambahan Berita Negara (Pasal 28 KUHD). Adapun ihtisar isi resmi dari Akta Pendirian CV yang dimaksud dalam Pasal 26 KUHD secara umum meliputi (1) identitas para pendiri persero (2) Penetapan nama CV (3) Keterangan mengenai CV itu bersifat umum atau terbatas untuk menjalankan sebuah perusahaan cabang secara khusus (4) Nama sekutu yang tidak berkuasa untuk menandatangani perjanjian atas nama persekutuan (5) Saat mulai dan berlakunya CV (6) kalusula lainnya yang berkaitan dengan pihak ketiga (7) tanggal didaftarakannya CV ke Pengadilan Negeri (8) modal dasar yang disetorkan. ${ }^{14}$ Uraian tersebut menunjukkan peranan Notaris dalam pendirian CV saat berlakunya KUHD hanya terbatas pada pembuatan akta otentik saja sedangkan kewajiban untuk mendaftarkannya dibebankan pada para persero dan kewajiban untuk mendaftarkan dibebankan kepada masing-masing sekutu dalam persekutuan.

Sejalan dengan perubahan-perubahan yang dilakukan dalam bidang perizinan berusaha di Indonesia, diterbitkanlah Peraturan Pemerintah No. 24 Tahun 2018 tentang Pelayanan Perizinan Berusaha Terintegrasi Secara Elektronik dikenal juga dengan Online Single Submission (OSS) sebagai titik tolak dan keseriusan pemerintah dalam pemberlakuan Permenkumham No. 17 Tahun 2018 Tentang Sistem Administrasi Badan Usaha yang merupakan pelayanan jasa teknologi informasi badan usaha secara elektronik yang diselenggarakan oleh Direktorat Jenderal Administrasi Hukum Umum. Ketentuan Pasal 3 Permenkumham 17/2018 menegaskan bahwa pendaftaran CV diajukan kepada Menteri dalam hal ini Menteri Hukum dan Hak Asasi Manusia melalui SABU.15

Mekanisme pendaftaran CV berdasarkan Permenkumham 17/2018 diatur dalam ketentuan Pasal 5 yaitu diawali dengan pengajuan nama $\mathrm{CV}$ dengan beberapa syarat yaitu, (1) ditulis dengan huruf latin (2) belum dipakai secara sah oleh CV lain dalam Sistem Administrasi Badan Usaha (3) tidak bertentangan dengan ketertiban umum, kesusilaan (4) tidak sama atau tidak mirip dengan nama lembaga negara dan (5)tidak terdiri atas angka atau rangkaian angka, huruf, atau rangkaian huruf yang tidak

${ }^{13}$ Erwinsyahbana, T., \& Melinda, M. (2018). Kewenangan dan Tanggung Jawab Notaris Pengganti setelah Pelaksanaan Tugas dan Jabatan Berakhir. Lentera Hukum, 5(2), 305-321.

14 Nasution, K., \& Kurniawan, A. (2019). PENDAFTARAN COMMANDITAIRE VENNOTSCHAP (CV) SETELAH TERBITNYA PERMENKUMHAM NO 17 TAHUN 2018. JHP17: Jurnal Hasil Penelitian, 4(01).

15 Utami, P. D. Y.(2020). PENGATURAN PENDAFTARAN BADAN USAHA BUKAN BADAN HUKUM MELALUI SISTEM ADMINISTRASI BADAN USAHA. Jurnal Komunikasi Hukum (JKH), 6(1), 1-19, h. 10. 
membentuk kata yang kemudian diajukan dengan mengisi form pengajuan nama (Pasal 5 ayat 3). Pengajuan nama ini dilakukan secara elektronik untuk mencegah adanya kesamaan dengan CV yang sudah berdiri sebelumnya seperti yang aturan yan ditetapkan dalam hal pendirian badan hukum PT. Selanjutnya setelah mengajukan nama CV, ketentuan Pasal 7 mewajibkan CV untuk mendapatkan persetujuan nama oleh Menteri, persetujuan mana diberikan secara elektronik yang memuat, nomor pemesanan nama $\mathrm{CV}$, nama $\mathrm{CV}$ yang dapat dipakai, tanggal pemesanan nama, tanggal daluwarsa dan kode pembayaran. Setelah proses pemesanan nama telah disetujui maka barulah ditindak lanjuti dengan pembuatan akta pendirian $\mathrm{CV}$ dan selanjutnya didaftarkan melalui SABU dengan mengunggah dokumen pendirian CV dan diterbitkannya Surat Keterangan Terdaftar, SKT mana termuat di dalamnya frasa bahwa merupakan SKT yang yang dicetak dan diperoleh dari Sistem Administrasi Badan Usaha kemudian ditandatangani dan di cap oleh Notaris.

Berdasarkan uraian tersebut diatas dapat disimpulkan bahwa Notaris memiliki peran yang lebih besar dalam CV, yaitu membantu persero dalam mengajukan pemesanan nama secara elektronik dalam SABU, setelah didapatkannya persetujuan tersebut membuatkan akta pendirian $\mathrm{CV}$, kemudian mendaftarkannya dan mencetak surat keterangan terdaftar CV sebagai pengesahan oleh Kementrian Hukum dan Hak Asasi Manusia.

\subsection{Kepastian Hukum Pendaftaran Persekutuan Komanditer Pada Sistem Administrasi Badan Usaha.}

Adanya tuntutan untuk melakukan penataan kembali mengenai sistem pendirian badan usaha di Indonesia, menjadi titik tolak dibuatnya Permenkumham 17/2018 yang diharapkan dapat mewujudkan kemudahan dalam mendirikan usaha khususnya CV. Melalui sistem administrasi badan usaha, pelaku usaha diharapkan dapat membantu para pelaku usaha melakukan pendaftaran badan usahanya. Landasan ini merupakan pintu gerbang dalam perbaikan sistem dan pelayanan dalam melakukan segala kegiatan usaha di Indonesia yang terintegrasi secara nasional.

Bila dilihat dari sudut pandang peraturan perundang-undangannya, terdapat dualisme hukum yang berlaku yaitu pendaftaran CV berdasarkan ketentuan KUHD dan pendaftaran CV berdasarkan ketentuan Permenkumham 17/2018. Sebelum membahas lebih lanjut mengenai kedua aturan tersebut maka perlu terlebih dahulu membahas kedudukan Permenkumham No. 17 Tahun 2018 dalam hierarki peraturan perundang-undangan di Indonesia. Menurut Hans kelsen, norma hukum adalah aturan, pola, atau standar yang perlu diikuti. Jika dikaitkan dengan Teori Jenjang Hukum (stufenbau theory) yang dikemukakannya bahwa norma-norma yang ada dibuat dan berlaku secara berjenjang mulai dari norma hukum yang paling rendah sampai dengan yang tertinggi sampai dengan Grundnorm atau norma dasar yang menjadi landasan pembentukan norma-norma di bawahnya. ${ }^{16}$

${ }^{16}$ Saraswati, R. (2013). Problematika Hukum Undang-Undang No. 12 Tahun 2011 tentang Pembentukan Peraturan Perundang-Undangan. Jurnal Yustisia, Edisi, 87. 
Pasal 7 Ayat (1) Undang-undang Nomor 12 Tahun 2011 tentang Pembentukan Peraturan Perundang-undangan menentukan hierarki peraturan perundangundangan di Indonesia didasari oleh Undang-Undang Dasar Negara Republik Indonesia Tahun 1945 sumber hukum tertinggi, Ketetapan Majelis Permusyawaratan Rakyat, Undang-Undang/Peraturan Pemerintah Pengganti Undang-Undang, Peraturan Pemerintah, Peraturan Presiden, Peraturan Daerah Provinsi, dan sampai pada Peraturan Daerah Kabupaten/Kota. Dengan demikian, pasal 7 ayat (1) ini memberikan kedudukan kepada KUHD sebagai Undang-Undang walaupun memang merupakan produk hukum warisan Belanda namun telah diakui berlaku dalam hukum positif di Indonesia. Sedangkan dalam Pasal 8 Ayat 1 mengatur mengenai peraturan-peraturan lainnya yang selain yang diatur dalam Pasal 7 ayat (1) tersebut diatas. Yang dimana Peraturan Menteri termasuk di dalamnya yang merupakan ketetapan oleh Menteri berdasarkan materi muatan tertentu dalam menyelenggarakan sutu urusan pemerintahan yang dibentuk atas perintah Undang-Undang. Sehingga dapat dipahami bahwa kedudukan Permenkumham lebih rendah dari KUHD. ${ }^{17}$

Dengan diberlakukannya peraturan tersebut tentu menimbulkan akibat hukum selain adanya pertentangan norma dan tumpang tindih peraturan yang berlaku, adanya pemberlakuan Permenkumham No. 17 Tahun 2018 juga menyebabkan ketidakpastian mekanisme dalam proses pendaftaran dan pendirian CV karena di satu sisi KUHD tidak dicabut dan digantikan dengan Undang-Undang yang baru seperti dalam pengaturan Perseroan Terbatas maka menyebabkan aturan tersebut harus tetap berlaku. ${ }^{18}$ Akan tetapi, di sisi lain Permenkumham No. 17 Tahun 2018 mewajibkan pendaftaran pendirian CV melalui SABU secara online. Dengan adanya pertentangan norma ini tentunya haruslah mencari solusi hukum yang dapat dijadikan sebagai jalan tengah guna mencapai kepastian hukum. Hal ini dapat dilakukan dengan mengacu pada asas hukum yang dapat dijadikan landasan dalam pembentukan dan pelaksanaan hukum yaitu dengan menggunakan asas Prefensi yaitu yang pertama Lex Specilais derogate Lex Generalis penerapan hukum yang bersifat lebih khusus yaitu dalam pembahasan ini adalah Permenkumham No 17 Tahun 2018 karena secara khusus dan menyebutkan pengaturan mengenai $\mathrm{CV}$ dapat menyampingkan penerapan hukum yang lebih umum yaitu KUHD yang sifatnya mengatur persekutuan secara umum saja. Meskipun secara hierarki Permenkumham merupakan peraturan yang kedudukannya lebih rendah dibandingkan KUHD, kebutuhan dalam menjalankan pelayanan yang terintergrasi secara elektronik lebih menyesuaikan dengan kondisi terkini di Indonesia. ${ }^{19}$ Permenkumham merupakan peraturan baru yang pelaksanaanya dinilai dapat memfasilitasi kebutuhan dan lebih menyesuaikan kemajuan zaman saat ini maka dapat diambil solusi selama peraturan di dalam KUHD belum dicabut atau diganti dengan Undang-Undang lainnya para pendiri CV

17 Maryoto, J. (2020). PENDAFTARAN PERSEKUTUAN KOMANDITER PASCA BERLAKUNYAPERATURAN MENTERI HUKUM DAN HAK ASASI MANUSIA REPUBLIK INDONESIA NOMOR 17 TAHUN 2018. Jurnal HUKUM BISNIS, 4(2), 485-498.

18 Violeta, A. C., Muryati, D. T., \& Astanti, D. I. (2020). KEDUDUKAN PERSEKUTUAN KOMANDITER DALAM KAITANNYA DENGANPERATURAN MENTERI HUKUM DAN HAK ASASI MANUSIA NOMOR 17 TAHUN 2018TENTANG PENDAFTARAN PERSEKUTUAN KOMANDITER, PERSEKUTUAN FIRMA, DAN PERSEKUTUAN PERDATA. Semarang Law Review (SLR), 1(2), 1-16. 
diharapkan mengikuti kedua aturan yang ditetapkan dengan melakukan pendaftaran dengan tata cara dalam Permenkumham No. 17 Tahun 2018 kemudian tetap di daftarkan sesuai ketentuan Pasal 23 KUHD.

\section{Kesimpulan}

Dalam praktik di Indonesia untuk pendaftaran dan pendirian CV baik sebelum dan sesudah diterbitkannya Permenkumham sama-sama memerlukan peran Notaris baik dalam hal membuat akta pendirian. Peran Notaris lebih setelah berlakunya Permenkumham 17 Tahun 2018 yaitu berperan dalam pendaftaran CV ke sistem administrasi badan usaha. Adanya Permenkumham menyebabkan pertentangan atau tumpang tindih peraturan perundang-undangan dan mengakibatkan adanya ketidak pastian hukum. Asas Lex Specilais derogate Lex Generalis yang penerapannya adalah hukum yang lebih khusus dapat mengesampingkan hukum yang lebih umum karena berkaitan dengan urgensi dalam membentuk suatu peraturan ketentuan Permenkumham tersebut sangatlah diperlukan adanya pengaturan $\mathrm{CV}$ yang mengikuti keadaan pendirian usaha saat ini mengingat KUHD merupakan peraturan yang cukup lama sehingga sifatnya belum modern. Diperlukan adanya suatu keselarasan dalam membentuk suatu Peraturan Menteri agar tetap merujuk kepada undang-undang yang lebih tinggi dan dapat disimpulkan dalam pendirian CV para pelaku usaha haruslah tetap mengikuti dan menjalankan ketentuan yang sesuai dengan KUHD dan mengikuti proses pendaftaran secara online melalui SABU sebagaimana yang diatur dalam Permenkumham. Selain itu juga dapat dilakukan kajian agar dibentuk suatu Undang-Undang yang baru yang dapat menggantikan ketentuan KUHD dalam pendaftaran $\mathrm{CV}$.

\section{Daftar Pustaka}

\section{$\underline{\text { Buku-Buku }}$}

Abdul Rasyid Saliman, 2011, Hukum Bisnis Untuk Perusahaan: Teori Dan Contoh Kasus, Kencana, Jakarta.

H.M.N Purwosutjipto, 1995, Pengertian Pokok Hukum Dagang Indonesia: Pengetahuan Dasar Hukum Dagang, Djambatan, Jakarta.

I.G. Rai Widjaya, 2007, Hukum Perusahaan, Kesaint Blanc.Bekasi.

Peter Mahmud Marzuki, 2011, Penelitian Hukum, Kencana, Jakarta.

Subekti, 1995, Aneka Perjanjian, PT. Citra Aditya Bakti, Bandung, hal. 75-76.

Titik Triwulan Tutik, 2008, Hukum Perdata dalam Sistem Hukum Nasional, Kencana.

\section{Jurnal}

Barus, Z. (2013). Analisis Filosofis Tentang Peta Konseptual Penelitian Hukum Normatif Dan Penelitian Hukum Sosiologis. Jurnal Dinamika Hukum, 13(2), 307-318. 
Erwinsyahbana, T., \& Melinda, M. (2018). Kewenangan dan Tanggung Jawab Notaris Pengganti setelah Pelaksanaan Tugas dan Jabatan Berakhir. Lentera Hukum, 5(2), 305321.

Maryoto, J. (2020). PENDAFTARAN PERSEKUTUAN KOMANDITER PASCA BERLAKUNYA PERATURAN MENTERI HUKUM DAN HAK ASASI MANUSIA REPUBLIK INDONESIA NOMOR 17 TAHUN 2018. Jurnal HUKUM BISNIS, 4(2), 485498.

Nasution, K., \& Kurniawan, A. (2019). PENDAFTARAN COMMANDITAIRE VENNOTSCHAP (CV) SETELAH TERBITNYA PERMENKUMHAM NO 17 TAHUN 2018. JHP17: Jurnal Hasil Penelitian, 4(01).

Partyani, K. C. M. (2019). PERTENTANGAN NORMA DALAM PENGATURAN PENDAFTARAN DAN PENDIRIAN COMMANDITAIRE VENNOOTSCHAP (CV). Vyavahara Duta, 14(1), 68-77.

Permadi, I. M. H. (2019). Pengaturan Mengenai Pendaftaran Pendirian Firma Pada Sistem Administrasi Badan Usaha. Acta Comitas: Jurnal Hukum Kenotariatan, 4(3).

Permana, I. G. A. (2019). Penggunaan Upaya Hukum Novasi Dalam Penyelesaian Permasalahan Hukum Perusahaan Yang Mengalami Kerugian. Acta Comitas: Jurnal Hukum Kenotariatan, 4(2).

Ratnawati, A. 2015. Peranan Notaris Untuk Pembuatan Akta Pendirian (CV) dalam Mewujudkan Kepastian Hukum. Jurnal Repertorium. Vol. 2 No. 2

Saraswati, R. (2013). Problematika Hukum Undang-Undang No. 12 Tahun 2011 tentang Pembentukan Peraturan Perundang-Undangan. Jurnal Yustisia, Edisi, 87.

Utami, P. D. Y. (2020). PENGATURAN PENDAFTARAN BADAN USAHA BUKAN BADAN HUKUM MELALUI SISTEM ADMINISTRASI BADAN USAHA. Jurnal Komunikasi Hukum (JKH), 6(1), 1-19

Violeta, A. C., Muryati, D. T., \& Astanti, D. I. (2020). KEDUDUKAN PERSEKUTUAN KOMANDITER DALAM KAITANNYA DENGANPERATURAN MENTERI HUKUM DAN HAK ASASI MANUSIA NOMOR 17 TAHUN 2018TENTANG PENDAFTARAN PERSEKUTUAN KOMANDITER, PERSEKUTUAN FIRMA, DAN PERSEKUTUAN PERDATA. Semarang Law Review (SLR), 1(2), 1-16.

\section{Undang-Undang}

Kitab Undang-Undang Hukum Perdata

Kitab Undang-Undang Hukum Dagang

Undang-Undang Nomor 12 Tahun 2011 tentan Pembentukan Peraturan PerundangUndangan, Lembaran Negara Republik Indonesia Tahun 2011 Nomor:82. 
Peraturan Menteri Hukum dan Hak Asasi Manusia Nomor 17 Tahun 2018 tentang Pendaftaran Persekutuan Komanditer, Persekutuan Firma dan Persekutuan Perdata, Tambahan lembaran Negara Republik Indonesia Nomor 1011. 